\title{
Korelasi Komponen Pertumbuhan dan Hasil pada Pertanian Terpadu Padi-Azolla
}

\author{
Correlation of Growth and Product Components on Integrated Farming Rice-Azolla \\ Etty Safriyani ${ }^{\left.1,2^{*}\right)}$, Mery Hasmeda ${ }^{2}$, Munandar Munandar $^{2}$, dan Firdaus Sulaiman ${ }^{2}$ \\ ${ }^{1}$ Program Studi Agroteknologi, Fakultas Pertanian, Universitas Musi Rawas, \\ Kota Lubuklinggau, Sumatera Selatan 31625 \\ ${ }^{2}$ Program Studi Doktor Ilmu Pertanian, Fakultas Pertanian, Universitas Sriwijaya, \\ Indralaya, Sumatera Selatan 30862 \\ ${ }^{*}$ Penulis untuk korespondensi: ettysafriyani72@yahoo.co.id
}

\begin{abstract}
In order to increase the growth and production of rice plants that support sustainable agriculture can be done with the azolla application. This study aimed to evaluate the correlation of the components of growth and yield on rice-azolla production. The research was conducted on Karang Ketuan Subdistrict South Lubuklinggau II Subdistrict Lubuklinggau City from January to April 2018. This study used a randomized block consisting of K1=250 kg urea ha ${ }^{-1}$ without azolla, K2=250 kg urea ha ${ }^{-1}+$ azolla 1000 $\mathrm{kg} \mathrm{ha}^{-1}, \mathrm{~K} 3=187.5 \mathrm{~kg}$ urea ha ${ }^{-1}+$ azolla $1000 \mathrm{~kg} \mathrm{ha}^{-1}, \mathrm{~K} 4=125 \mathrm{~kg}^{-1}$ urea ha ${ }^{-1}+$ azolla $1000 \mathrm{~kg}$ $\mathrm{ha}^{-1}, \mathrm{~K} 5=62.5 \mathrm{~kg}$ urea ha ${ }^{-1}+$ azolla1000 kg ha ${ }^{-1}, \mathrm{~K} 6=$ without Urea+azolla1000 kg ha ${ }^{-1}$. Data analysis used correlation and path analysis. The results showed that plant height and number of pithy grains correlated on grain weight with higher values than other growth components. Dry weight of straw and harvest index have a direct and positive effect on grain weight with cross coefficients value namely 1.086 and 0.755 representatives. Plant height and number of pithy grains can be used as an indicator of crop production.
\end{abstract}

Keywords: grain weight, path analysis, residual value

\begin{abstract}
ABSTRAK
Peningkatan pertumbuhan dan produksi tanaman padi yang mendukung pertanian berkelanjutan dapat dilakukan dengan aplikasi azolla. Penelitian ini bertujuan engevaluasi korelasi komponen pertumbuhan dan hasil terhadap produksi padi-azolla. Penelitian telah dilaksanakan di Kelurahan Karang Ketuan Kecamatan Lubuklinggau Selatan II Kota Lubuklinggau. Penelitian berlangsung dari bulan Januari sampai bulan April 2018. Penelitian menggunakan rancangan acak kelompok yang terdiri dari $\mathrm{K} 1=250 \mathrm{~kg}^{-}$urea ha ${ }^{-1}$ tanpa azolla, K2=250 kg urea ha ${ }^{-1}+$ azolla $1000 \mathrm{~kg} \mathrm{ha}^{-1}, \mathrm{~K} 3=87.5 \mathrm{~kg}$ urea ha ${ }^{-1}+$ azolla 1000 $\mathrm{kg} \mathrm{ha}^{-1}, \mathrm{~K} 4=125 \mathrm{~kg}$ urea ha ${ }^{-1}+$ azolla $1000 \mathrm{~kg} \mathrm{ha}^{-1}, \mathrm{~K} 5=62.5 \mathrm{~kg}$ urea ha ${ }^{-1}+$ azolla $1000 \mathrm{~kg}$ $\mathrm{ha}^{-1}, \mathrm{~K} 6=$ tanpa pupuk Urea+azolla $1000 \mathrm{~kg} \mathrm{ha}^{-1}$. Analisis data menggunakan uji korelasi dan sidik lintas. Hasil penelitian menunjukkan bahwa tinggi tanaman dan jumlah gabah bernas berkorelasi dengan berat gabah dengan nilai lebih tinggi dibandingkan komponen pertumbuhan dan hasil lainnya, dengan nilai koefesien korelasi yang sama yaitu 0.95 . Berat kering jerami dan indeks panen memiliki pengaruh langsung dan positif terhadap berat gabah dengan koefesien lintas sebesar 1.086 dan 0.755 . Tinggi tanaman dan jumlah gabah bernas dapat dijadikan indikator produksi tanaman.
\end{abstract}

Kata kunci: sidik lintas, berat gabah, nilai residu 


\section{PENDAHULUAN}

Padi merupakan salah satu tanaman pangan penting di Indonesia, karena tanaman padi merupakan sumber karbohidrat utama sebagian besar masyarakat Indonesia. Tahun 2014 luas lahan padi mencapai 13,79 juta hektar, produksi 70,84 juta ton gabah kering giling dengan produktifitas $51.35 \mathrm{ku} \mathrm{ha}^{-1}$. Tahun 2015 luas lahan padi mengalami peningkatan menjadi 14,11 juta hektar, produksi 75,39 juta ton gabah kering giling (GKG) dengan produktivitas $53.41 \mathrm{ku} \mathrm{ha}^{-1}$ (Kementrian Pertanian, 2016). Salah satu unsur hara yang berperan dalam mempengaruhi produkstivitas tanaman padi adalah nitrogen.

Sumber nitrogen tanaman padi selain berasal dari pupuk urea juga dapat bersumber dari azolla. Azolla merupakan tanaman pakis berukuran kecil yang dapat menyediakan nitrogen bagi tanaman padi. Kemampuan azolla dalam mengfiksasi nitrogen diudara 30-60 $\mathrm{kg} \mathrm{N}^{-1}$ (Kollah et al. 2016). Aplikasi azolla pada tanaman padi dapat meningkatkan kandungan unsur hara tanah (Cheng et al. 2015), meningkatkan tinggi tanaman, jumlah anakan produktif, luas daun, berat dan kering tanaman (Castro et al. 2003; Bhuvaneshwari dan Singh 2015) dan dapat mempercepat pertumbuhan tanaman padi 15-21 hari (Mahalingam et al. 2014).

Karakter komponen pertumbuhan dan komponen hasil sangat mempengaruhi daya hasil tanaman. Keeratan hubungan antar karakter komponen tersebut dapat diketahui melalui analisis korelasi. Korelasi mengukur derajat keeratan hubungan linier diantara dua karakter atau lebih. Korelasi antar dua karakter dapat berupa korelasi komponen pertumbuhan maupun korelasi komponen hasil tanaman (Safitri et al. 2011). Analisis sidik lintas merupakan pengembangan dari analisis korelasi. Analisi sidik lintas dapat menghasilkan hubungan dan pengaruh antar karakter baik secara langsung maupun tidak langsung. Pengaruh langsung maksudnya komponen hasil memberikan pengaruh terhadap hasil tanpa melalui komponen lainnya, sedangkan pengaruh tidak langsung artinya pengaruh suatu komponen terhadap hasil harus melalui komponen lain, baik berasal dari komponen pertumbuhan maupun komponen hasil (Chandrasari et al. 2013). Penelitian ini bertujuan untuk mengevaluasi korelasi komponen pertumbuhan dan hasil terhadap produksi padi-azolla.

\section{BAHAN DAN METODE}

Penelitian telah dilaksanakan di Kelurahan Karang Ketua Kecamatan Lubuklinggau Selatan II Kota Lubuklinggau. Penelitian berlangsung selama 4 bulan, dari bulan Januari sampai bulan April 2018. Penelitian menggunakan metode eksperimen dengan rancangan acak kelompok, yang terdiri dari $\mathrm{K} 1=250 \mathrm{~kg}$ urea $\mathrm{ha}^{-1}$ tanpa azolla, K2 $=250 \mathrm{~kg}$ urea $\mathrm{ha}^{-}$ ${ }^{1}$ +azolla $1000 \mathrm{~kg} \mathrm{ha}^{-1}, \mathrm{~K} 3=187.5 \mathrm{~kg}$ urea ha ${ }^{1}$ +azolla $1000 \mathrm{~kg} \mathrm{ha}^{-1}, \mathrm{~K} 4=125 \mathrm{~kg}$ urea ha ${ }^{1}$ +azolla $1000 \mathrm{~kg} \mathrm{ha}^{-1}, \mathrm{~K} 5=62.5 \mathrm{~kg}$ urea ha ${ }^{1}+$ azolla $1000 \mathrm{~kg} \mathrm{ha}^{-1}$, K6=tanpa pupuk Urea+azolla $1000 \mathrm{~kg} \mathrm{ha}^{-1}$.

Penanaman dilakukan pada areal tanam seluas $500 \mathrm{~m}^{2}$. Sebelum ditanam, tanah diolah menggunkan cangkul pada kedalaman kurang lebih $25 \mathrm{~cm}$. Penyebaran azolla dilakukan 7 hari sebelum penanaman padi, sebanyak $100 \mathrm{~g} \mathrm{~m}^{-2}$. Bibit azolla berasal dari biomassa Azolla segar yang masih muda yang berasal dari perbanyakan azolla yang dilakukan di kolam terpal di lokasi penelitian.

Benih padi varietas Inpari 42 disemai dibedeng semai dengan ukuran 3 $\mathrm{m} \times 4 \mathrm{~m}$. Setelah bibit berumur 14 hari setelah semai, bibit ditanam dipetak penelitian dengan jarak tanam $25 \mathrm{~cm}$ x 25 $\mathrm{cm}$. Penanaman dilakukan sebanyak 2 bibit per lubang tanam dengan kedalaman $5 \mathrm{~cm}$.

Pemeliharaan tanaman padi meliputi penyulaman dilakukan 10 hari setelah tanam. Pupuk urea diberikan 3 kali yaitu saat tanam, tanaman berumur 30 hari setelah tanam dan 60 hari setelah tanam dengan dosis sesuai perlakuan. Tinggi muka 
air dipertahankan $5 \mathrm{~cm}$ mulai saat tanam padi sampai tanaman padi berumur 80 hst.

Peubah yang diamati adalah tinggi tanaman $(\mathrm{cm})$, jumlah anakan, jumlah malai rumpun $^{-1}$, jumlah gabah rumpun ${ }^{-1}$, berat

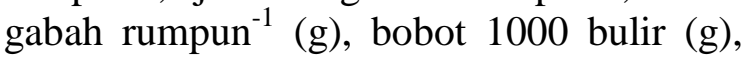
indeks panen, berat kering jerami. Data hasil pengamatan diolah secara statistik menggunakan analisis korelasi dan sidik lintas menggunakan prosedur Singh dan Chaudhary (1979), dengan aplikasi program SPSS versi 21.

\section{HASIL}

Korelasi Antar Karakter Pertumbuhan, Komponen Hasi dan Hasil

Hubungan antar karakter komponen pertumbuhan, komponen hasil dan hasil padi-azolla dapat dilihat dari nilai korelasi. Hasil analisis korelasi antar berbagai karakter komponen pertumbuhan, komponen hasil dan hasil padi-azolla (Tabel 1). Tinggi tanaman berkorelasi nyata dan positif dengan jumlah anakan rumpun ${ }^{-1}$, berat kering jerami rumpun ${ }^{-1}$, jumlah malai rumpun $^{-1}$, jumlah gabah bernas rumpun ${ }^{-1}$, berat 1000 bulir, indeks panen dan berat gabah rumpun ${ }^{-1}$.

Kondisi ini menunjukkan bahwa peningkatan tinggi tanaman padi diikuti oleh peningkatan anakan rumpun ${ }^{-1}$, berat kering jerami rumpun $^{-1}$, jumlah malai rumpun $^{-1}$, jumlah gabah bernas rumpun ${ }^{-1}$, berat 1000 bulir, indeks panen dan berat gabah rumpun $^{-1}$. Data penelitian ini mendukung pendapat Safitri et al. (2011), bahwa tinggi tanaman padi berkorelasi sangat nyata dan positif dengan panjang malai, jumlah gabah isi malai ${ }^{-1}$, jumlah gabah total malai ${ }^{-1}$, dan bobot 1000 bulir gabah. Berarti peningkatan tinggi tanaman sampai batas tertentu akan diikuti oleh peningkatan produksi, tetapi tanaman yang terlalu tinggi dapat menurunkan produksi karena tanaman mudah rebah (Riyanto et al. 2012).

Tabel 1. Nilai koefisien korelasi antara karakter komponen pertumbuhan, komponen hasil dan hasil padi-azolla

\begin{tabular}{lcccccccc}
\hline Karakter & TT & JA & BKJ & JM & JGB & B1000 & IP & BG \\
\hline TT & 1.00 & $0.96^{* * *}$ & $0.92^{* *}$ & $0.97^{* *}$ & $0,99^{* *}$ & $0.77^{* *}$ & $0.20^{* *}$ & $0.95^{* *}$ \\
JA & & 1.00 & $0.82^{* *}$ & $0.92^{* *}$ & $0.93^{* *}$ & $0.64^{* *}$ & $0.35^{*}$ & $0.92^{* *}$ \\
BKJ & & & 1.00 & $0.89^{* *}$ & $0.95^{* *}$ & $0.64^{* *}$ & -0.08 & $0.90^{* *}$ \\
JM & & & & 1.00 & $0.99^{* *}$ & $0.78^{* *}$ & $0.29^{*}$ & $0.94^{* *}$ \\
JGB & & & & & 1.00 & $0.74^{* *}$ & -0.17 & $0.95^{* *}$ \\
B1000 & & & & & & 1.00 & $0.37^{*}$ & $0.74^{* *}$ \\
IP & & & & & & & 1.00 & $0.35^{*}$ \\
BG & & & & & & & & 1.00 \\
\hline
\end{tabular}

Keterangan: $\mathrm{TT}=$ tinggi tanaman, $\mathrm{JA}=$ jumlah anakan, $\mathrm{BKJ}=$ berat kering jerami, $\mathrm{JM}=$ jumlah malai, JGB = jumlah gabah bernas, IP = indeks panen, B1000 = berat 1000 bulir, $\mathrm{BG}=$ berat gabah, ${ }^{*}$ nyata pada taraf $5 \%$, nyata pada taraf $1 \%$.

Pengaruh Langsung dan Tak Langsung Antar Karakter Komponen Pertumbuhan, Komponen Hasi dan Hasil (sidik lintas)

Koefesienkorelasi menggambarkan tingkat keeratan antar karakter yang satu dengan karakter lainnya, tetapi nilai korelasi tidak dapat menjelaskan secara jelas hubungan karakter komponen pertumbuhan, komponen hasil dan hasil baik secara langsung maupun secara tidak langsung melalui karakter lainnya. Maka diperlukan analisis sidik lintas, sehingga nilai korelasi antar peubah bebas dan tak bebas dapat dipisahkan menjadi pengaruh langsung dan tidak langsung suatu peubah terhadap hasil tanaman (Rohaeni dan Permadi 2012).

Hasil analisis sidik lintas antar berbagai karakter komponen pertumbuhan, 
komponen hasil dan hasil padi-azolla (Gambar 1.).

Hasil analisis sidik lintas menunjukkan bahwa karakter yang memiliki pengaruh langsung dan positif yang lebih besar terhadap berat gabah dibandingkan dengan karakter lainnya adalah berat kering jerami dengan nilai koefisien lintas 1.086 dan indeks panen dengan nilai koefisien lintas 0.755 . Sebaliknya tinggi tanaman dan jumlah anakan menghasilkan pengaruh langsung yang negatif terhadap berat gabah, dengan nilai koefisien lintas -0.115 dan -0.054 . Karakter yang memiliki pengaruh tidak langsung yang besar dan positif terhadap berat gabah adalah jumlah anakan melalui tinggi tanaman dengan nilai koefisien lintas 0.636, dan jumlah gabah bernas melalui tinggi tanaman, jumlah anakan dan berat kering jerami dengan nilai koefisien lintas 0.785 (Gambar 1).

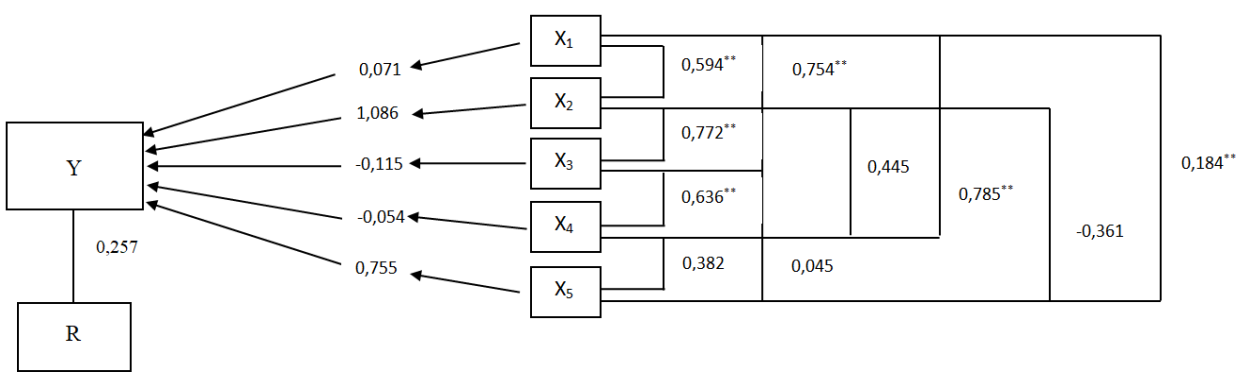

Keterangan:

$\mathrm{X} 1=$ Gabah bernas; $\mathrm{X} 2$ = Berat kering jerami; $\mathrm{X} 3$ = Tinggi tanaman; $\mathrm{X} 4$ = Jumlah anakan; $\mathrm{X} 5$ = Indeks panen; $\mathrm{Y}=$ Berat gabah; $\mathrm{R}=$ Residual

Gambar 1. Diagram analisis sidik lintas komponen pertumbuhan, komponen hasil dengan berat gabah padi sawah irigasi.

\section{PEMBAHASAN}

Hasil uji korelasi menunjukkan bahwa tinggi tanaman berkorelasi nyata dan positif terhadap karakter komponen pertumbuhan dan hasil tanaman padi-azolla. Hasil ini menggambakan bahwa peningkatan tinggi tanaman dapat meningkatkan kemampuan tanaman dalam menghasilkan fotosintat, karena daun merupakan organ utama yang melakukan fotosintesa yang akan memyusun biomassa tanaman. Hasil fotosintat akan ditranslokasikan ke organ vegetatif dan generatif yang membutuhkannya. Selama fase vegetatif tanaman mempersiapkan berbagai organnya terutama daun untuk lebih mampu memasuki fase generatif, dengan bertambahnya radiasi yang dapat diserap daun pada priode ini akan digunakan tanaman untuk membentuk organ generatif, dengan terbentuknya sink utama yaitu gabah. Sarathi (2011) menyatakan bahwa pertumbuhan vegetatif akan menentukan fase generatif dan produksi tanaman.

Jumlah anakan rumpun ${ }^{-1}$ berkorelasi nyata dan positif dengan berat kering jerami rumpun $^{-1}$, jumlah malai rumpun ${ }^{-1}$, jumlah gabah bernas rumpun ${ }^{-1}$, berat 1000 bulir, indeks panen dan berat gabah rumpun ${ }^{-1}$. Hal ini mengindikasikan bahwa tanaman yang memiliki jumlah anakan rumpun ${ }^{-1}$ yang banyak akan menghasilkan berat kering jerami rumpun $^{-1}$, jumlah malai rumpun $^{-1}$, jumlah gabah bernas rumpun ${ }^{-1}$, berat 1000 bulir, indeks panen dan berat gabah rumpun $^{-1}$ yang tinggi. Sejalan dengan hasil penelitian Riyanto et al., (2012), dimana jumlah anakan total dan jumlah anakan produktif rumpun $^{-1}$ berkorelasi positif dengan bobot gabah rumpun ${ }^{-1}$. Hal yang sama juga didapat oleh Rachmawati et al., (2014), dimana peningkatan jumlah 
anakan akan diikuti oleh peningkatan hasil gabah.

Berat kering jerami rumpun $^{-1}$ mempunyai korelasi nyata dan positif dengan jumlah malai rumpun $^{-1}$, jumlah gabah bernas rumpun ${ }^{-1}$, berat 1000 bulir, dan berat gabah rumpun ${ }^{-1}$, tetapi berkorelasi negatif terhadap indeks panen. Berarti semakin tinggi berat kering jerami rumpun ${ }^{-1}$ akan diikuti oleh peningkatan jumlah malai rumpun $^{-1}$, jumlah gabah bernas rumpun ${ }^{-1}$, berat 1000 bulir, dan berat gabah rumpun ${ }^{-1}$, tetapi akan menurunkan indeks panen. Berat kering jerami tanaman padi menggambarkan kemampuan tanaman dalam mengikat energi dari cahaya matahari melalui proses fotosintesis, dan interaksinya dengan faktor-faktor lingkungan lainnya, karena $90 \%$ berat kering tanaman berasal dasri fotosintesa. Akumulasi bahan kering tanaman terdistribusi kebagian akar, batang, daun dan bagian generatif tanaman, yang menggambarkan produktivitas tanaman.

Jumlah malai rumpun ${ }^{-1}$ mempunyai korelasi nyata dan positif dengan jumlah gabah bernas rumpun ${ }^{-1}$, berat 1000 bulir, indeks panen dan berat gabah rumpun ${ }^{-1}$. Data ini mengindikasikan bahwa semakin banyak jumlah malai rumpun $^{-1}$ yang dihasilkan tanaman padi akan diikuti oleh peningkatan jumlah gabah bernas rumpun ${ }^{-1}$, berat 1000 bulir, indeks panen dan berat gabah rumpun $^{-1}$. Hal ini sejalan dengan hasil penelitian Rachmawati et al. (2014) dimana jumlah malai rumpun $^{-1}$ korelasi nyata dan positif dengan hasil gabah rumpun $^{-1}$. Besar kecilnya jumlah malai, jumlah gabah bernas dan berat 1000 bulir yang dihasilkan tanaman padi, akan mempengaruhi berat gabah yang dihasilkan, karena potensi produksi padi merupakan perkalian jumlah malai, jumlah gabah bernas malai ${ }^{-1}$ dan berat 1000 bulir (Yoshida 1981).

Jumlah gabah bernas rumpun $^{-1}$ tanaman padi diikuti oleh peningkatan berat 1000 bulir dan berat gabah rumpun ${ }^{-1}$, seperti ditunjukkan oleh nilai korelasi yang nyata dan positif (Tabel 1). Sebaliknya peningkatan gabah bernas rumpun ${ }^{-1}$ akan menurunkan indeks panen, karena menghasilkan nilai korelasi negatif. Artinya semakin banyak jumlah gabah bernas rumpun $^{-1}$ akan meningkatkan berat 1000 bulir dan berat gabah rumpun ${ }^{-1}$. Hal ini sejalan dengan hasil penelitian Kartina et al. (2016) dimana peningkatan jumlah gabah isi malai ${ }^{-1}$ akan diikuti dengan peningkatan jumlah gabah total dan persentase pengisian biji. Berat 1000 bulir mempunyai korelasi nyata dan positif dengan indeks panen dan berat gabah rumpun $^{-1}$, dengan demikian peningkatan berat 1000 bulir akan meningkatkan indeks panen dan berat gabah rumpun ${ }^{-1}$. Berat 1000 bulir menggambarkan ukuran dan kebernasan gabah. Gabah yang besar dan pengisian yang penuh akan menghasilkan indeks panen dan berat gabah rumpun ${ }^{-1}$ yang tinggi. Sejalan dengan hasil penelitian Kartina et al. (2017), bobot 1000 bulir memiliki korelasi positif dengan hasil gabah, kondisi ini menunjukkan bahwa bobot 1000 bulir memiliki keeratan hubungan dengan hasil gabah.

Indeks panen mempunyai korelasi nyata dan positif dengan berat gabah rumpun $^{-1,}$ berarti peningkatan indeks panen akan diikuti oleh peningkatan berat gabah rumpun $^{-1}$. Indeks panen merupakan perbandingan antara bobot kering hasil ekonomis (gabah) dengan bobot kering biomasa (hasil biologis) bagian atas tanaman. Semakin tinggi berat gabah yang dihasilkan akan meningkatkan indeks panen tanaman padi.

Secara keseluruhan peningkatan berat gabah rumpun $^{-1}$ dapat diperoleh dengan penigkatan tinggi tanaman jumlah anakan rumpun ${ }^{-1}$, berat kering jerami rumpun $^{-1}$, jumlah malai rumpun ${ }^{-1}$, jumlah gabah bernas rumpun ${ }^{-1}$, berat 1000 bulir dan indeks panen. Kondisi ini menunjukkan bahwa tanaman padi yang menghasilkan berat gabah rumpun ${ }^{-1}$ yang tinggi, dicirikan oleh pertumbuhan vegetatif dan generatif yang maksimal. Hal ini sejalan dengan hasil penelitian Safitri et al. 2011) yang dilakukan pada padi haploid ganda 
hasil kultur antera.

Hasil analisis sidik lintas menunjukkan bahwa berat kering jerami dan indeks panen berpengaruh langsung dan positif terhadap berat gabah. Berat kering jerami menggambarkan jumlah biomassa yang menyusun tanaman, karena berat kering jerami merupakan akumulasi berat bersih asimilasi $\mathrm{CO}_{2}$ yang terjadi selama proses pertumbuhan dan perkembangan tanaman. Semakin tinggi berat kering jerami maka akumulasi fotosintat pada organ generatif terutama gabah juga meningkat.

Indeks panen menggambarkan perbandingan fotosintat yang ditranslokasikan ke bagian generative tanaman dalam bentuk gabah. Indeks panen merupakan perbandingan antara berat kering hasil panen biologi (bobot kering biomassa) dan hasil panen ekonomi (gabah), yang dipengaruhi oleh besarnya translokasi fotosintat. Semakin tinggi indeks panen tanaman mengindikasikan bahwa hasil fotosintat di tajuk banyak ditranslokasi ke bagian biji, yang akan meningkatkan hasil gabah yang dihasilkan. Peningkatan indeks panen akan diikuti oleh peningkatan hasil gabah.

Tinggi tanaman secara tidak langsung mempengaruhi jumlah gabah bernas dan berat gabah, karena tinggi tanaman menggambarkan besarnya proporsi tajuk sebagai source. Tajuk merupakan salah satu bagian tanaman yang berperan penting dalam proses fotosintesa (Kartina $e t$ al. (2017). Semakin banyak fotosintat yang dihasilkan akan mempengaruhi peningkatkan berat gabah karena tanaman yang tinggi akan memiliki jumlah malai yang lebih banyak. Sejalan dengan hasil penelitian Rohaeni dan Permadi (2012), dimana tinggi tanaman dapat meningkatkan hasil panen padi organik.

Jumlah anakan secara tidak langsung mempengaruhi jumlah gabah bernas dan berat gabah, karena tanaman yang memiliki jumlah anakan yang banyak, akan meningkatkan jumlah anakan produktif. Tanaman yang memiliki jumlah anakan yang banyak akan meningkatkan jumlah gabah bernas yang dihasilkan. Hal ini juga tercermin dari nilai korelasi antara jumlah anakan dengan jumlah gabah bernas dan berat gabah yang bernilai positif dan nyata (Tabel 1). Didukung oleh hasil penelitian yang dilakukan Riyanto et al. (2012), jumlah anakan rumpun ${ }^{-1}$ berkorelasi positif dan nyata dengan jumlah gabah rumpun $^{-1}$.

Nilai residu merupakan nilai sisa dari total pengaruh langsung yang belum terhitung pada karakter yang belum diindetifikasi. Nilai residu mempengaruhi keragaman berat gabah yang diukur dari tinggi tanaman, jumlah anakan, berat kering jerami, gabah bernas dan indeks panen. Hasil nilai residu yang mendekati nol, menandakan bahwa analisis sidik lintas yang digunakan efektif menjelaskan sebab akibat nilai korelasi dan karakter yang diamati secara lengkap baik dari nilai pengaruh langsung dan tidak langsung (Rohaeni dan Permadi 2012). Nilai residu yang dihasilkan pada penelitian ini sebesar $\mathrm{R}=0.257$, menggambarkan bahwa faktor lain yang mempengaruhi karakter berat gabah sebesar $25.7 \%$.

\section{KESIMPULAN}

Berat kering jerami dan indeks panen memiliki pengaruh langsung dan positif terhadap berat gabah dengan koefesien lintas sebesar 1.086 dan 0.755 . Tinggi tanaman dan jumlah gabah bernas dapat dijadikan indikator produksi tanaman.

\section{UCAPAN TERIMAKASIH}

Peneliti mengucapkan terimakasih kepada Lembaga Pengelola Dana Pendidikan yang telah membiayai penelitian melalui Beasiswa Unggulan Dosen Indonesia dalam Negeri (Nomer kontrak: PRJ-5916/LPDP.3/2016). 


\section{DAFTAR PUSTAKA}

Bhuvaneshwari K dan Singh PK. 2015. Response of nitrogen-fixing water fern Azolla biofertilization to rice crop. Journal Biotech. (5):523-529.

Castro R, Novo R dan Castro RI. 2003. Influnce of Azzola-Anabaena Symbiosis on Rice (Oryza sativa $\mathrm{L}$ ) Crop as a Nutrional Alternative. Journal Cultivos Tropicales.77-82.

Chandrasari, Suciati, Nasrullah, dan Sutardi. 2013. Uji daya hasil delapan galur harapan padi sawah. Vegetalika. 1(2): 99-107.

Cheng W, Takei M, Sato C, Kautsar V, Sasaku Y, Sato S, dan Yasuda H. 2015. Combined use of Azolla and loach suppressed paddy weeds and increased organic rice yield: second season results. Journal Wetlands Environmental Managemen.t 3(1):113.

Kartina N, Wibowo PW, dan Widyastuti Y. 2016. Korelasi sidik lintas karater agronomi padi hibrida. Jurnal Ilmu Pertanian Indonesia. 21(2): 76-83.

Kartina N, Wibowo BP, Rumanti IR, dan Satoto. 2017. Korelasi hasil gabah dan komponen hasil padi hibrida. Jurnal Pertanian Tanaman Pangan. 1(1):11-19.

Kementrian Pertanian. 2016. www. pertanian.co.id [Diakses Juni 2018].

Kollah B, Patra AK, dan Mohanty SR. 2016. Aquatic microphylla Azolla: A perspective paradigm for sustainable agriculture, environment and global climate change. Journal Environmental Science and Pollution. 23(5):4358-4369.

Mahalingam PU, Muniappan K, dan Arumugam N. 2014. Use of azolla biofertilizer in pot culture studies with paddy crop Oryza Sativa. Journal Agriculture Science. 2(3):15.

Riyanto A, Widiatmoko T, dan Hartanto B. 2012. Korelasi antar komponen hasil dan hasil pada padi genotip F5 keturunan persilangan G39 X Ciherang. Prosiding Seminar Nasional"Pengembangan sumber daya pedesaan dan kearifan lokal berkelanjutan" Purwokerto 27-28 November 2012.

Rachmawati RY, Kuswanto, dan Purnamaningsih SL. 2014. Uji keseragaman dan analisis sidik lintas antara karakter agronomis dengan hasil pada tujuh genotip padi hibrida Japonica. Jurnal Produksi Tanaman. 2(4):292-300.

Rohaeni WR dan Permadi K. 2012. Analisis sidik lintas beberapa komponen hasil terhadap daya hasil padi sawah pada aplikasi agrisimba. Jurnal Agrotrop 2(2): 185-190.

Safitri H, Purwanto BS, Dewi IS, dan Abdullah B. 2011. Korelasi dan sidik lintas karakter fenotifikgalurgalur padi haploid ganda hasil kultur antera. Jurnal Widyariset 14(2):295-302.

Sarathi P. 2011. Effect of seedling age on tillering pattern and yield of rice (Oryza sativa L.) under system of rice intensification. ARPN Journal of Agriculture and Biological Science. 6(11):67-69.

Yoshida S. 1981. Fundamentals of Rice Crop Science. Los Banos, Philippines: Internasional Rice Research Institute. 